\title{
Note ON THE OPTIMUM PRICING OF ANNUITIES
}

\author{
EYTAN SHESHINSKI
}

\author{
CESIFO WORKING PAPER NO. 884 \\ CATEGORY 1: Public FinANCE \\ MARCH 2003
}
An electronic version of the paper may be downloaded
- from the SSRN website: www.SSRN.com
- from the CESifo website: www.CESifo.de




\title{
Note On THE OPTIMUM PRICING OF ANNUITIES
}

\begin{abstract}
In a perfectly competitive market for annuities with full information, the price of annuities is equal to individuals' (discounted) survival probabilities. That is, prices are actuarially fair. In contrast, the pricing implicit in social security systems invariably allows for cross subsidization between different risk groups (males/females). We examine the utilitarian approach to the optimum pricing of annuities and show how the solution depends on the joint distribution of survival probailities and incomes in the population.
\end{abstract}

JEL Code: G23, H55.

\author{
Eytan Sheshinski \\ Department of Economics \\ The Hebrew University of Jerusalem \\ Mount Scopus \\ Jerusalem 91905 \\ Israel \\ mseytan@mscc.huji.ac.il
}




\section{Introduction}

In a perfectly competitive market for annuities with full information, the price of annuities is equal to individuals (discounted) survival probabilities. That is, prices are actuarially fair . In contrast, the pricing implicit in social security systems invariably allows for cross subsidization between different risk groups, implying transfers from high to low risk individuals. For example, most social security systems provide the same bene ts to males and females of equal age with equal income and retirement histories in spite of the higher life expectancy of females. ${ }^{1}$

We want to examine the utilitarian approach to this issue using the theory of optimum commodity taxation. Consider a population that consists of $H$

\footnotetext{
${ }^{1}$ Further subsidization is provided when females are allowed to retire earlier.
} 
individuals. Denote the expected utility of individual $h$ by $U_{h}, h=1,2, \ldots, H$. Utilitarianism attempts to maximize a social welfare function, $W$, which depends on the $U_{h} \mathrm{~s}$ :

$$
W=W\left(U_{1}, U_{2}, \ldots, U_{H}\right) .
$$

$W$ depends positively on, and is assumed to be symmetric in, the $U_{h}$ s.

Each individual lives for either one or two periods, and individuals differ in their survival probabilities. Let $p_{h}$ be the probability that individual $h$ lives for two periods; $c_{1 h}$ be consumption of individual $h$ in period 1 and $c_{2 h}$ be consumption of individual $h$ in period 2 , if he or she is living then. Utility derived from consumption, $c>0$, by any individual in any period during life is $u(c)(>0)$. It is the same in either period so there is no time preference. When not alive, utility is 0. Expected utility of individual $h$ is thus

$$
U_{h}=u\left(c_{1 h}\right)+p_{h} u\left(c_{2 h}\right) .
$$

The economy has a given amount of resources, $R$, which can be used in either period and they can be carried forwards without any gain or loss. With a large number of individuals, expected consumption in the two periods must therefore equal the given resources:

$$
\sum_{h=1}^{H} c_{1 h}+\sum_{h=1}^{H} p_{h} c_{2 h}=R
$$

Maximization of (1) s.t. (3) yields the condition that consumption is equal in both periods, $c_{1 h}=c_{2 h}=c_{h}$, for all $h=1,2, \ldots, H$. Consequently, expected utility, (2), becomes $U_{h}=u\left(c_{h}\right)\left(1+p_{h}\right)$ and the resource constraint, (3), is $\sum_{h=1}^{H} c_{h}\left(1+p_{h}\right)=R$. The First-Best optimum allocation of consumption, $c_{h}$, among individuals depends on the welfare function as given by the F.O.C.

$$
\frac{\partial W}{\partial U_{h}} u^{\prime}\left(c_{h}\right)=\text { constant, for all } h=1,2, \ldots, H .
$$

For the case of an additive $W$, i.e. the sum of expected utilities, condition (4) implies equal consumption for all: $c_{h}=c ; h=1,2, \ldots, H$.

Optimum consumption, satisfying (3) and (4), can be supported by a competitive annuity market accompanied by an optimum income distribution. In a competitive (full information) market with a zero rate of interest, 
annuities, i.e. second period consumption, are priced by survival probabilities. Individuals maximizing expected utility subject to a budget constraint

$$
c_{1 h}+p_{h} c_{2 h}=y_{h} \quad h=1,2, \ldots, H,
$$

where $y_{h}$ is individual $h \mathrm{~s}$ income, choose $c_{1 h}=c_{2 h}=c_{h}=\frac{y_{h}}{1+p_{h}}$. There is typically a unique allocation of incomes that supports the First-Best, condition (4). In particular, with additive $W$, the optimum $y_{h}$ are proportional to $p_{h}$ :

$$
y_{h}=\frac{1+p_{h}}{\sum_{h=1}^{H}\left(1+p_{h}\right)} \cdot R
$$

Accordingly, optimum consumption is equal in all periods and for all individuals: $c_{1 h}=c_{2 h}=\frac{R}{\sum_{h=1}^{H}\left(1+p_{h}\right)} ; h=1,2, \ldots, H$. Optimum expected utility, on the other hand, increases with $p_{h}: U_{h}=u\left(\frac{R}{\sum_{h=1}^{H}\left(1+p_{h}\right)}\right)\left(1+p_{h}\right)$. Hence, the utilitarian First-Best optimum has inequality in expected utilities and equality in consumption levels, as pointed out by Arrow (1992). This result is similar to Mirrlees optimum income tax model (1971) where individuals differ in their productivity. ${ }^{2}$ Maximization of the sum of utilities leads to a First Best allocation that provides higher (expected) utility to those with a higher capacity to produce utility. This result carries over for all general concave (egalitarian) welfare functions. ${ }^{3}$

\section{Optimum Pricing of Annuities}

Governments cannot engage in unconstrained lump-sum redistributions of incomes. In contrast, most annuities are supplied directly by government-run

\footnotetext{
${ }^{2}$ In Mirrlees model with additive utilities, the First-Best has all individuals with equal consumption and those with higher productivity, having a lower disutility for generating income, are assigned to produce a higher income and hence have a lower utility.

${ }^{3}$ In the extreme case, with $W=\operatorname{Min}\left[U_{1}, U_{2}, \ldots, U_{H}\right]$, expected utilities are equalized, i.e. $U_{h}=u\left(\frac{y_{h}}{1+p_{h}}\right)\left(1+p_{h}\right)=$ constant for all $h=1,2, \ldots, H$. Since utility is concave, this implies that $c_{h}=\frac{y_{h}}{1+p_{h}}$ and $y_{h}$ decrease with $p_{h}$.
} 
social security systems and taxes/subsidies can be applied to annuity prices offered by private pension funds. Prices of annuities can thus be used by governments to improve social welfare. Although deviations from actuarially fair prices entail distortions (i.e., efficiency losses), distributional improvements may outweigh the costs.

Suppose individual $h$ purchases annuities at a price of $q_{h}$. With an income $y_{h}$, his or her budget constraint is

$$
c_{1 h}+q_{h} c_{2 h}=y_{h}, \quad h=1,2, \ldots, H
$$

Maximization of (2) subject to (7) yields demands $\hat{c}_{i h}=\hat{c}_{i h}\left(q_{h}, p_{h}, y_{h}\right), i=$ 1,2 , and $h=1,2, \ldots, H$. Maximized expected utility, $\hat{U}_{h}$, is $\hat{U}_{h}\left(q_{h}, p_{h}, y_{h}\right)=$ $u\left(\hat{c}_{1 h}\right)+p_{h} u\left(\hat{c}_{2 h}\right)$.

Assume that total subsidies/taxes on annuities must equal zero,

$$
\sum_{h=1}^{H}\left(q_{h}-p_{h}\right) \hat{c}_{2 h}=0
$$

Maximization w.r.t prices $\left(q_{1}, \ldots, q_{H}\right)$ of $W\left(\hat{U}_{1}, \hat{U}_{2}, \ldots, \hat{U}_{H}\right)$ subject to $(8)$ yields F.O.C.

$$
\frac{\partial W}{\partial \hat{U}_{h}} \frac{\partial \hat{U}_{h}}{\partial q_{h}}+\lambda\left[\hat{c}_{2 h}+\left(q_{h}-p_{h}\right) \frac{\partial \hat{c}_{2 h}}{d q_{h}}\right]=0, \quad h=1,2, \ldots, H,
$$

where $\lambda>0$ is the shadow price of constraint (8). In elasticity form, using Roy s identity $\left(\frac{\partial \hat{U}_{h}}{\partial q_{h}}=-\frac{\partial \hat{U}_{h}}{\partial y_{h}} \hat{c}_{2 h}\right),(9)$ can be written

$$
\frac{q_{h}-p_{h}}{q_{h}}=\frac{\theta_{h}}{\varepsilon_{h}}
$$

where $\varepsilon_{h}=-\frac{q_{h}}{\hat{c}_{2 h}} \frac{\partial \hat{c}_{2 h}}{\partial q_{h}}$ is the price elasticity of second period consumption of individual $h$, and $\theta_{h}=1-\frac{1}{\lambda} \frac{\partial W}{\partial \hat{U}_{h}} \frac{\partial \hat{U}_{h}}{\partial y_{h}}$ is the net social value of a marginal transfer to individual $h$ through the optimum pricing scheme. Equation (10) is a variant of the well-known inverse-elasticity optimum tax formula which combines equity $\left(\theta_{h}\right)$ and efficiency $\left(\frac{1}{\varepsilon_{h}}\right)$ considerations.

The implication of (10) for the optimum pricing of annuities depends on the welfare function, $W$, and on the joint distribution of incomes, $\left(y_{1}, \ldots, y_{H}\right)$, and probabilities $\left(p_{1}, \ldots, p_{H}\right)$. 
For concreteness, let $W$ be the sum of expected utilities. Then $\frac{\partial W}{\partial \hat{U}_{h}}=$ $1, h=1,2, \ldots, H$. Assume further that $U_{h}=\ln c_{1 h}+p_{h} \ln c_{2 h}$. Then,

$$
\hat{c}_{1 h}=\frac{y_{h}}{1+p_{h}} \quad ; \quad \hat{c}_{2 h}=\frac{y_{h}}{1+p_{h}} \frac{p_{h}}{q_{h}}
$$

and

$$
\hat{U}_{h}=\left(1+p_{h}\right) \ln \left(\frac{y_{h}}{1+p_{h}}\right)+p_{h} \ln \left(\frac{p_{h}}{q_{h}}\right)
$$

Conditions (10) and (8) now yield the solution

$$
\begin{gathered}
q_{h}=\phi\left(\frac{\beta_{h}}{\sum_{h=1}^{H} \beta_{h}}\right), \\
\text { where } \phi=\sum_{h=1}^{H} p_{h}>0 \text { and } \beta_{h}=\frac{p_{h} y_{h}}{1+p_{h}}>0
\end{gathered}
$$

Consider two special cases of (13):

(a) Equal Incomes: $\left(y_{h}=y=\frac{R}{H} ; h=1, \ldots, H\right.$. $)$

Condition (13) becomes $q_{h}=\bar{\phi}\left(\frac{p_{h}}{1+p_{h}}\right)$, where $\bar{\phi}=\frac{\sum_{h=1}^{H} p_{h}}{\sum_{h=1}^{H}\left(\frac{p_{h}}{1+p_{h}}\right)}(>1)$.

It is seen (Figure 1) that optimum pricing involves subsidization (taxation) of individuals with high (low) survival probabilities. ${ }^{4}$

(b) $\underline{y_{h}=y\left(1+p_{h}\right)}$

This, one recalls, is the First-Best utilitarian income distribution and since all price elasticities are equal to unity, we see from (13), as expected, that $q_{h}=p_{h}$, i.e., efficiency prices.

\footnotetext{
${ }^{4}$ For Figure 1, it can be shown that $\frac{\bar{\phi}}{2}<1$.
} 
More generally, it is seen from (13) that a higher correlation between incomes, $y_{h}$, and survival probabilities, $p_{h}$, decreases - and possibly eliminates - the subsidization of high survival individuals. In contrast, a negative correlation between incomes and survival probabilities (as, presumably, in the female/male case) leads to subsidies for high survival individuals, possibly to the commonly observed uniform pricing rule.

\section{References}

[1] Arrow, K.J., (1992), Sex Differentiation in Annuities: Re ections on Utilitarianism and Inequality, in R. Selten (ed.) Rational Interactions (Springer), pp.333-336

[2] Mirrlees, J.A. (1971), An Exploration in the Theory of Optimal Income Taxation , Review of Economic Studies, 38 (114), April, pp. 175-208. 


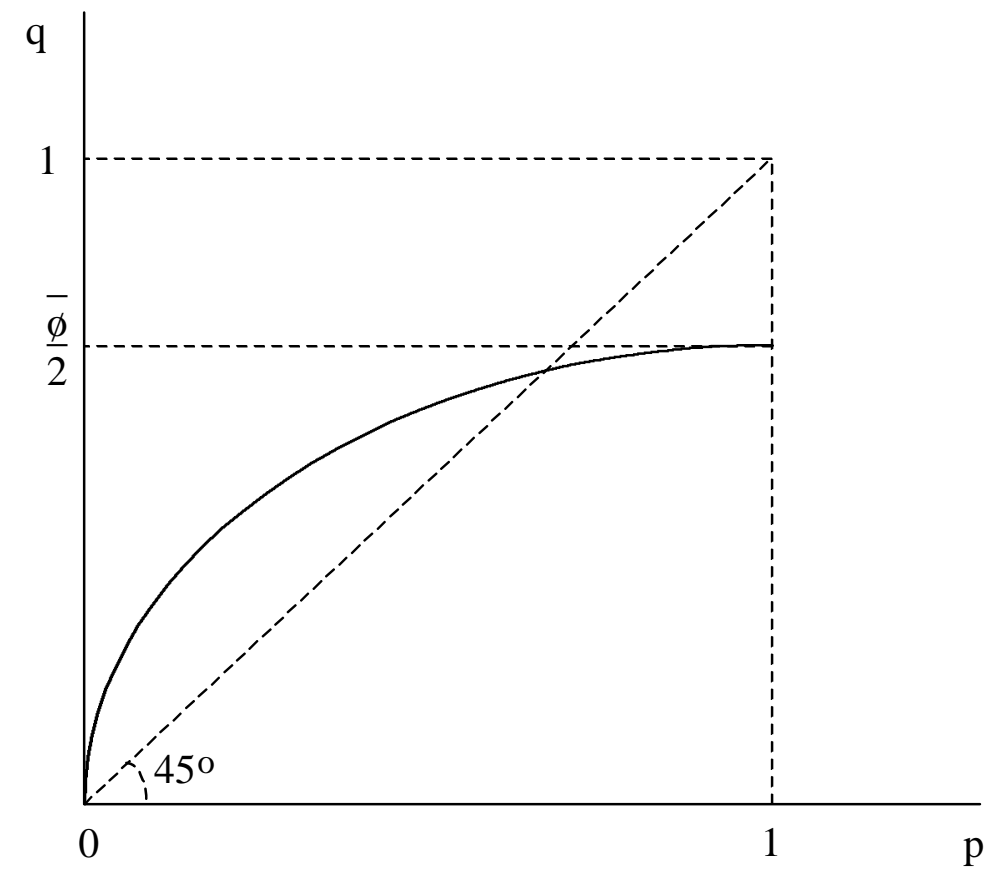

Figure 1 


\title{
CESifo Working Paper Series
}

\author{
(for full list see www.cesifo.de)
}

821 Hans Gersbach and Verena Liessem, Financing Democracy, December 2002

822 Costas Hadjiyiannis, Panos Hatzipanayotou, and Michael S. Michael, Optimal Tax Policies with Private-Public Clean-Up, Cross-Border Pollution and Capital Mobility, December 2002

823 François Ortalo-Magné and Sven Rady, Homeownership: Low Household Mobility, Volatile Housing Prices, High Income Dispersion, December 2002

824 Syed M. Ahsan and Panagiotis Tsigaris, Measuring the Social Discount Rate under Uncertainty: A Methodology and Application, December 2002

825 Kai A. Konrad, Altruism and Envy in Contests: An Evolutionarily Stable Symbiosis, December 2002

826 Robert S. Chirinko and Huntley Schaller, A Revealed Preference Approach to Understanding Corporate Governance Problems: Evidence from Canada, December 2002

827 Geir B. Asheim, Green National Accounting for Welfare and Sustainability: A Taxonomy of Assumptions and Results, December 2002

828 Andrea Gebauer, Chang Woon Nam, and Rüdiger Parsche, Lessons of the 1999 Abolition of Intra-EU Duty Free Sales for Eastern European EU Candidates, December 2002

829 Giacomo Corneo, Work and Television, December 2002

830 Vivek H. Dehejia and Yiagadeesen Samy, Trade and Labour Standards - Theory, New Empirical Evidence, and Policy Implications, December 2002

831 Geir B. Asheim and Wolfgang Buchholz, A General Approach to Welfare Measurement through National Income Accounting, December 2002

832 Aaron Tornell and Frank Westermann, The Credit Channel in Middle Income Countries, January 2003

833 Gebhard Flaig, Time Series Properties of the German Monthly Production Index, January 2003

834 Campbell Leith and Jim Malley, Estimated Open Economy New Keynesian Phillips Curves for the G7, January 2003

835 Burkhard Heer and Bernd Süssmuth, Inflation and Wealth Distribution, January 2003 
836 Erkki Koskela and Leopold von Thadden, Optimal Factor Taxation under Wage Bargaining - A Dynamic Perspective, January 2003

837 Carola Grün and Stephan Klasen, Growth, Income Distribution, and Well-Being: Comparisons across Space and Time, January 2003

838 Robert S. Chirinko and Ulf von Kalckreuth, On the German Monetary Transmission Mechanism: Interest Rate and Credit Channels for Investment Spending, January 2003

839 Sascha O. Becker, Andrea Ichino, and Giovanni Peri, How Large is the "Brain Drain" from Italy?”, January 2003

840 Albert Berry and John Serieux, All About the Giants: Probing the Influences on Growth and Income Inequality at the End of the $20^{\text {th }}$ Century, January 2003

841 Robert Fenge and Martin Werding, Ageing and the Tax Implied in Public Pension Schemes: Simulations for Selected OECD Countries, January 2003

842 Robert Fenge and Martin Werding, Ageing and Fiscal Imbalances Across Generations: Concepts of Measurement, January 2003

843 Giovanni Andrea Cornia, The Impact of Liberalisation and Globalisation on Income Inequality in Developing and Transitional Economies, January 2003

844 Peter Fredriksson and Per Johansson, Program Evaluation and Random Program Starts, January 2003

845 Bernd Hayo and Matthias Wrede, Fiscal Equalisation: Principles and an Application to the European Union, January 2003

846 Syed M. Ahsan and Jaideep Oberoi, Inequality, Well-being and Institutions in Latin America and the Caribbean, January 2003

847 Chang Woon Nam and Doina Maria Radulescu, The Role of Tax Depreciation for Investment Decisions: A Comparison of European Transition Countries, January 2003

848 V. Bhaskar and Steinar Holden, Wage Differentiation via Subsidised General Training, January 2003

849 Paloma Lopez-Garcia, Labour Market Performance and Start-up Costs: OECD Evidence, January 2003

850 Christian Keuschnigg and Soren Bo Nielsen, Public Policy for Start-up Entrepreneurship with Venture Capital and Bank Finance, January 2003

851 Yin-Wong Cheung, Menzie D. Chinn, and Eiji Fujii, China, Hong Kong, and Taiwan: A Quantitative Assessment of Real and Financial Integration, January 2003

852 Gregory D. Hess, The Economic Welfare Cost of Conflict: An Empirical Assessment, February 2003 
853 Douglas J. Cumming and Jeffrey G. MacIntosh, Comparative Venture Capital Governance. Private versus Labour Sponsored Venture Capital Funds, February 2003

854 Eckhard Janeba and John Douglas Wilson, Decentralization and International Tax Competition, February 2003

855 Tapio Palokangas, Capital Accumulation and Employment Cycles in a Model of Creative Destruction, February 2003

856 Brendan Walsh, When Unemployment Disappears: Ireland in the 1990s, February 2003

857 Luis H. R. Alvarez and Erkki Koskela, A General Approach to the Stochastic Rotation Problem with Amenity Valuation, February 2003

858 Christian Schultz, Strategic Campaigns and Redistributive Politics, February 2003

859 Ernst Fehr and Joseph Henrich, Is Strong Reciprocity a Maladaptation? On the Evolutionary Foundations of Human Altruism, February 2003

860 Haizhou Huang, Dalia Marin, and Chenggang Xu, Financial Crisis, Economic Recovery and Banking Development in Former Soviet Union Economies, February 2003

861 Pedro Cardoso and Bernard M.S. van Praag, How Sustainable Are Old-age Pensions in a Shrinking Population with Endogenous Labour Supply?, February 2003

862 Volker Meier, Efficient Transfer of Aging Provisions in Private Health Insurance, February 2003

863 Edward Castronova, Theory of the Avatar, February 2003

864 Robert S. Chirinko, Hans van Ees, Harry Garretsen, and Elmer Sterken, Investor Protections and Concentrated Ownership: Assessing Corporate Control Mechanisms in the Netherlands, February 2003

865 Bernard M.S. van Praag and Pedro Cardoso, The Mix Between Pay-as-you-go and Funded Pensions and what Demography has to do with it, February 2003

866 Ernst Fehr, Urs Fischbacher, Bernhard von Rosenbladt, Jürgen Schupp, and Gert G. Wagner, A Nation-Wide Laboratory. Examining Trust and Trustworthiness by Integrating Behavioral Experiments into Representative Survey, February 2003

867 Frank Heinemann, The Inflationary Impact of Wage Indexation, February 2003

868 Eytan Sheshinski, Bounded Rationality and Socially Optimal Limits on Choice in a Self-Selection Model, February 2003

869 M. Hashem Pesaran, Estimation and Inference in Large Heterogenous Panels with Cross Section Dependence, February 2003 
870 Luis H. R. Alvarez and Erkki Koskela, On the Tree-Cutting Problem under Interest Rate and Forest Value Uncertainty, February 2003

871 Norbert Berthold and Rainer Fehn, Unemployment in Germany: Reasons and Remedies, February 2003

872 Clemens Fuest, Bernd Huber, and Philipp Tilleßen, Tax Policy and Entrepreneurship in the Presence of Asymmetric Information in Capital Markets, February 2003

873 Eytan Sheshinski, Optimum and Risk-Class Pricing of Annuities, February 2003

874 Willi Leibfritz, Paul O'Brien and Jean-Christophe Dumont, Effects of Immigration on Labour Markets and Government Budgets - An Overview, February 2003

875 M. Hashem Pesaran and Allan Timmermann, How Costly is it to Ignore Breaks when Forecasting the Direction of a Time Series?, February 2003

876 Thorvaldur Gylfason and Gylfi Zoega, Education, Social Equality and Economic Growth: A View of the Landscape, February 2003

877 Robin Boadway and Jean-François Tremblay, Public Economics and Startup Entrepreneurs, February 2003

878 Erkki Koskela and Roope Uusitalo, The Un-Intended Convergence: How the Finnish Unemployment Reached the European Level, February 2003

879 Robert Fenge and Volker Meier, Pensions and Fertility Incentives, February 2003

880 Eytan Sheshinski, Note on Income Taxation and Occupational Choice, February 2003

881 A B Atkinson, Income Inequality in OECD Countries: Data and Explanations, February 2003

882 Thomas Gehrig and Rune Stenbacka, Venture Cycles: Theory and Evidence, February 2003

883 Ralf Becker and Thomas Hellmann, The Genesis of Venture Capital - Lessons from the German Experience, March 2003

884 Eytan Sheshinski, Note on the Optimum Pricing of Annuities, March 2003 